Article

\title{
Ranking of Sustainability Journals Using the Author Affiliation Index and Comparison to Other Journal Metrics
}

\author{
Matías Ginieis * (D) and Xiaoni Li \\ Department of Business Management, Faculty of Business and Economics, Universitat Rovira i Virgili, \\ 43204 Reus, Tarragona, Spain; xiaoni.li@urv.cat \\ * Correspondence: matias.ginieis@urv.cat
}

Received: 9 December 2019; Accepted: 1 February 2020; Published: 4 February 2020

\begin{abstract}
An important component in evaluating research productivity is the quality of the academic journal. For this reason, the objective of this paper is to analyze the Author Affiliation Index (AAI) in sustainability field journals as a preliminary study to offer some insights into quality rating of journals in this chosen discipline. The AAI of a journal is defined as the percentage of the journal's articles published by authors affiliated with a base set of high-quality academic universities or institutions. We conducted an evaluation of the top 50 journals in environmental studies indexed in the category Social Science in the Web of Science (WOS) database in 2018 and the top-notch 50 universities worldwide with master or postgraduate programs in the disciplines of management and sustainability studies. The results obtained demonstrate that there is a low AAI score on average in the sustainability field compared with other disciplines and the potential reason for such low scoring is probably caused by the high number of co-authors collaborating in environmental studies related journals. Although there is no agreement reached in terms of journal ratings by AAIs and other citation and survey-based measures, we can confirm certain elite affiliations effect which leading sustainability journals have higher concentrations of authors who are affiliated with elite institutions, however, such elite affiliation effect is on average much lower compared with other disciplines as finance, accounting or transportation, etc.
\end{abstract}

Keywords: sustainability; journal ranking; author affiliation; research productivity; authorship pattern; journal quality; environmental research; higher education; university

\section{Introduction}

Academic journals have been studied repeatedly to determine the best in terms of quality. Various statistical tools such as regression analysis [1], stochastic dominance analysis [2], structural equation models [3] or correlation coefficients [4,5] have been applied in the literature. Different research has been carried out using more descriptive statistical techniques, such as cross-tabulation techniques [6], mapping techniques and metrics [7]. Some other work is carried out by adopting previously defined indicators as databases of doctoral theses on accounting [8] or selecting indicators such as institutions that have won Nobel Prizes and Fields Medals [9].

Moreover, there are several studies that have analyzed patterns in publications between journals and the author affiliations. Some examples related to this type of analysis can be seen in the field of environmental sciences [10,11], medicine [12,13], information sciences [14,15], management [16], engineering sciences [17], and biological sciences [18].

Accordingly, the purpose of this study is to analyze through the Author Affiliation Index (AAI) a set of journals, in this case the fifty most prestigious journals, that mainly address issues related to 
sustainability. Chan et al. [19] (p. 407) explain that "... A journal's AAI is defined as the percentage of the journal's articles authored by scholars from a predetermined set of top programs ..." . Therefore, the AAI is calculated to determine if academics from the most prestigious universities in the field of sustainability publish in the main academic journals on the subject. In our research, we calculate the AAI to determine the relationship that can be established between academics of the top-ranking universities and the best journals that mostly publish issues related to sustainability.

Several authors [19-22] indicate that the AAI is an alternative journal ranking method to bibliometric indicators. Gorman and Kanet [23] emphasize that it is "a robust measure" in the sense that it is "... relatively objective, transparent, and stable" (p. 17).

At the same time, [20] suggest that university academics are attracted to present and publish their research in the best journals and the AAI is a method that measures a journal in relation to the affiliation of its publishers. A high AAI means that the quality of the journal is higher because academics from the most prestigious universities are supposed to produce and publish better quality research.

There are generally two approaches for measuring a journal's quality: citation analysis and survey rankings [20,24]. Citation measures are based on the argument that higher citation counts demonstrate that the research has received more interest from the public and, therefore, has greater impact in the field. Actually, databases, such as WOS or Scopus, adopt this approach to ranking although these measures for quality may have certain limitations and biases. Journals with a longer time of circulation and those that publish more articles each year are likely to generate higher citation counts [24]. Self-citation or coercive self-citation [25] may also be problematic for citation-based ranking.

The survey rankings approach considers that journal choices by scholars or experts are important and quality ranking can be carried out by subjective assessment of knowledgeable individuals in a particular discipline [26-28]. The Academic Journal Guide (ABS) rating has applied this approach of quality measurement. However, some authors indicate that the survey approach presents biases in questionnaire design, respondents' perceptions and sampling [29-31].

Although citation-based and survey-based quality measures are frequently applied, there are still concerns raised in the literature regarding these two approaches. In this context, as an alternative measure we studied the AAI method that was originally conceived in 1998 by David Harless and Robert J. Reilly of the Department of Economics at the University of Virginia Commonwealth School of Business to evaluate the journals quality in economics [32]. The initial objective of the method was to establish an objective indicator that measures the quality of a journal and allows its comparison between disciplines within business administration. Subsequently, this method was completed and developed by the authors Gorman and Kanet [23].

The AAI index has been created to be an objective indicator that measures the quality of journals within the scope of economics and business administration [23]. However, the AAI has been used to evaluate academic journals from different fields of study, such as operations management journals [23], financial journals [21], accounting journals [19,20,24], transport journals [33] and information systems journals [34], among other examples.

The philosophy of the AAI is that researchers and professors from the best universities or masters' programs ranked according to international rankings would seek to publish their research in journals that have high quality in different international databases. In other words, it aims to show that the quality of a journal is highly correlated with the authors who publish in it. Logically, academic authors aspire to publish in those journals where the scholars from the top-ranking universities actually publish [19-23].

Therefore, the objective of this paper can be stated as two-fold. First, this study aims to describe and examine the usefulness of an alternative quality rating measurement for accessing environmental studies and sustainability journal quality. AAI has been applied for alternative ranking of journals in many disciplines, such as finance [20,35-37], accounting [19,20,38] and economics [39-42], etc. However, to the best of our knowledge from review of previous literature, it has not yet been used in the discipline of sustainability and environmental science. Second, this research compares the ranking 
of journals provided by the AAI method with other ranking criteria, such as Web of Science (WOS), Scopus and Chartered Association of Business Schools (ABS), so as to display the difference in ranking results of AAI with other citation or survey-based rating measures.

The rest of the paper is organized as follows. Section 2 describes the methodology and data. Section 3 presents the empirical results and discussion. Conclusions are presented in the last section.

\section{Methodology}

\subsection{Formula}

The original Author Affiliation Index (AAI) formula was set by Harless and Reilly [32] aiming to have an optional ranking for journal quality. Gorman and Kanet [23] applied the AAI in evaluating operations management journals using the following calculation:

$$
A A I_{j}=\frac{\sum_{i \in m} \frac{x_{i}}{n_{i}}}{\sum_{i \in m} \frac{\left(x_{i}+y_{i}\right)}{n_{i}}}
$$

where $A A I_{j}$ measures the Author Affiliation Index for journal $j ; x_{i}$ is the number of authors from a set of peer group institutions $(x)$ in article $i ; y_{i}$ is the number of US academic authors in article $i$ not from the peer group institution set. Moreover, $n$ is the total number of authors in article $i$ and $m$ represents the sample size drawn from each journal $j$.

As commented by Chen and Huang [21], bias may arise from this formula of calculation, as bias regarding non-US academics and non-academics is inherent for this way of application. Therefore, we follow Chen and Huang [21] and redefine the dataset $(x+y)$ as all authors for article $i$ not taking into account their affiliations (non-academics, US or non-US academics). Accordingly, $x$ is defined to include all top-tier universities globally. Therefore, similarly as applied by Guthrie et al. [24], the AAI score is obtained by the sum of equivalent papers from top-notch universities in green, sustainability and environmental studies divided by the sum of equivalent papers by all authors, where equivalent papers indicate that each of the $\mathrm{n}$ authors of an article is given credit for $1 / \mathrm{n}$. The calculation example of AAI applying our definition of $(x+y)$ is displayed in Table 1 .

Table 1. Sample of Author Affiliation Index (AAI) calculations.

\begin{tabular}{cccc}
\hline Article & Author Affiliations & $\begin{array}{c}\text { Contribution to } \\
\text { Numerator }\end{array}$ & $\begin{array}{c}\text { Contribution to } \\
\text { Denominator }\end{array}$ \\
\hline 1 & University of Melbourne; University of Exeter & 1.00 & 1.00 \\
2 & University of California, Berkeley & 1.00 & 1.00 \\
3 & Carleton University, Ottawa; Colorado State University; University of & 0.00 & 1.00 \\
4 & Cornell University; University of Leeds; University of Manchester & 0.67 & 1.00 \\
5 & Oxford University; University of East Anglia & 0.50 & 1.00 \\
Total & AAI $=3.16 / 5=0.63$ & 3.17 & 5.00 \\
\end{tabular}

Source: Authors.

\subsection{Sample Construction}

To conduct our study, our sample of journals comprises the 50 top journals of the Web of Science (WOS) database from Clarivate Analytics (previously the Intellectual Property and Science business of Thomson Reuters). Only Social Sciences Citation Index (SSCI) journals included in two categories were selected: "Environmental Studies" and "Green and Sustainability Science and Technology." All journals of these two selected categories (in SSCI) were merged together and ranked according to Journal Impact Factor provided by the WOS. In Table A1 (in Appendix A), it can be observed that some of the 50 top journals are also categorized in "Business," "Management," "Economics" or other 
disciplines. The complete list of journals is shown in Table A1 and is sorted according to the Journal Impact Factor obtained by the journal in 2018, which is the last available year by the WOS database.

Then we proceeded to obtain the institutional sample for our dataset $x$. For this purpose, we selected the best universities in the world related to the subject of sustainability linked to the scope of management and environmental studies. First, it is necessary to clarify that we are aware of the existence of many classifications and different rankings. Nevertheless, we selected the top global universities in environmental science studies ranked by QS Top University ratings [43] because it includes and considers a larger number of ranking criteria in order to elaborate the "Overall Score" obtained by a University. For example, criteria such as "Academic Reputation," "Employer Reputation," "H-index Citations," "Citations per papers," among others are taken into account.

Moreover, we decided to use this ranking provided by QS Top University because many academics have used this database to carry out their respective investigations. For example, engineering and technology subjects [44]; life sciences and medicine subjects: psychology subject [45]; communication and media studies subjects [46]; mathematics subject [47] and global subjects have also been analyzed [48-50].

For our research, we have selected from this database the 50 top universities worldwide in the disciplines of sustainability and environmental studies that have the best overall qualifications. Additionally, these universities have the most prestigious master or postgraduate studies worldwide in sustainability within the scope of management and most have business schools or faculties with a clear orientation to sustainability. Table 2 presents the 50 universities selected, as well as what they do in terms of teaching in management and sustainability. To obtain this data, the master or postgraduate programs of each of the selected universities were carefully examined. As shown in Table 2, almost all 50 top-notch universities have master or postgraduate studies in management education with specifications in corporate social responsibility (CSR) or sustainability. Some universities, such as the University of California, Berkeley, have MBA programs specialized in socially responsible investing and others offer broader programs, like the University of Leeds which offers a master in sustainability and business. Some of the universities on this list have specialized centers for teaching and research in management and sustainability. These include the Center for Responsible Business in Berkeley University, the Laboratory for Sustainable Business in MIT and the Cambridge Institute for Sustainability Leadership. We consider that it is very crucial that future corporate managers take into account factors and issues related to sustainability and environmental aspects for decision-making instead of only financial or business perspectives. We can see progress in this direction based on these management related master's degrees or MBA programs with specialization in sustainable development or modules in sustainability, CSR and business ethics offered by our sample of top 50 universities. 
Table 2. Top 50 Universities worldwide with Master or postgraduate in management-related studies.

\begin{tabular}{|c|c|c|c|}
\hline Rank 2018 & University & Center/School in Business, Management or Economics & Location \\
\hline 1 & University of California, Berkeley & $\begin{array}{l}\text { Center for Responsible Business/Haas School of Business/MBA Strategic \& Sustainable Business Solutions; MBA } \\
\text { Socially Responsible Investing; MBA Haas Socially Responsible Investment Fund }\end{array}$ & United States \\
\hline 2 & Stanford University & Stanford Graduate School of Business/MBA & United States \\
\hline 3 & Massachusetts Institute of Technology & Sloan School of Management/Laboratory for Sustainable Business (S-Lab) 2017 Project Review & United States \\
\hline 4 & Harvard University & Harvard Business School/Sustainable Business Strategy & United States \\
\hline 5 & University of Oxford & Center of Responsible Business or Saïd Business School & United Kingdom \\
\hline 6 & ETH Zurich-Swiss Federal Institute of Technology & $\begin{array}{l}\text { Department of Management, Technology, and Economics/Master of Advanced Studies in Management, } \\
\text { Technology, and Economics }\end{array}$ & Switzerland \\
\hline 7 & University of Cambridge & Cambridge Institute for Sustainability Leadership/The Prince of Wales's Business \& Sustainability Programme & United Kingdom \\
\hline 8 & Wageningen University \& Research & Master's Management, Economics and Consumer Studies & Netherlands \\
\hline 9 & Imperial College London & Business School/MSc Management & United Kingdom \\
\hline 10 & National University of Singapore & Business School/Department of Management \& Organisation-MBA & Singapore \\
\hline 11 & University of British Columbia & Faculty of Commerce and Business Administration/Master of Management & Canada \\
\hline 12 & The University of Queensland & The University Of Queensland/Faculty of Business, Economics \& Law/Bachelor of Environmental Management & Australia \\
\hline 13 & University of California, Davis & Graduate School of Management/Managerial Economics or MBA & United States \\
\hline 14 & Delft University of Technology & Faculty of Technology, Policy and Management/MSc Industrial Ecology & Netherlands \\
\hline 15 & The University of New South Wales & UNSW Business School/AGSM MBA (Social Impact) & Australia \\
\hline 16 & University of California, Los Angeles & The Department of Public Policy/Masters in Public Policy: Environmental and Natural Resource Policy & United States \\
\hline 17 & Yale University & Yale School of Management/The joint-degree MBA in Environmental Management & United States \\
\hline 18 & Nanyang Technological University, Singapore & Nayyang Business School/Centre for Business Sustainability/MBA, Master in Business Analytics & Singapore \\
\hline 19 & California Institute of Technology & $\begin{array}{l}\text { Department of Environmental Science and Engineering/Master programme in Environmental Science } \\
\text { and Engineering }\end{array}$ & United States \\
\hline 20 & Cornell University & Johnson Cornell SC Johnson College of Business/MBA-Sustainable Global Enterprise & United States \\
\hline 22 & University of Washington & Daniel J. Evans School of Public Policy and Governance/Master in Environmental Policy and Management & United States \\
\hline 23 & The University of Melbourne & Office for Environmental Programms/Master of Environment & Australia \\
\hline 24 & Tsinghua University & $\begin{array}{c}\text { School of Public Policy and Management/Dual Degree Master in Innovation, Human Development } \\
\text { and Sustainability }\end{array}$ & China \\
\hline 25 & The University of Tokyo & Graduate School of Frontier Sciences/Master in Sustainability Science & Japan \\
\hline 26 & Peking University & Guanghua School of Management/Master of Social Enterprise Management & China \\
\hline 27 & University of Michigan & Stephen M. Ross School of Business/MBA: Sustainability Concentration & United States \\
\hline 28 & Princeton University & $\begin{array}{c}\text { Woodrow Wilson School of Public and International Affairs/Science, Technology, and Environmental Policy } \\
\text { for Master }\end{array}$ & United States \\
\hline 29 & McGill University & Desautels Faculty of Management, the McGill School of Environment/Executive MBA Sustainability Module & Canada \\
\hline 30 & Duke University & FUQUA school of Business/Nicolas School of the Environment/Master of Environmental Management & United States \\
\hline 31 & Seoul National University & Institute for Sustainable Development/Master of Sustainability and Environmental Policy & South Korea \\
\hline 32 & University of Texas at Austin & McCombs School of Business/MBA specialized in corporate social innovation & United States \\
\hline 33 & Stockholm University & Stockholm Business School/Master's Programme in Management, Organization and Society & Sweden \\
\hline 34 & University of Wisconsin-Madison & $\begin{array}{l}\text { The Wisconsin School of Business/Certificate in Business, Environment, and Social Responsibility for all } \\
\text { master students }\end{array}$ & United States \\
\hline 35 & University of Toronto & Institute for Management \& Innovation/Master of Science in Sustainability Management & Canada \\
\hline
\end{tabular}


Table 2. Cont

\begin{tabular}{|c|c|c|c|}
\hline Rank 2018 & University & Center/School in Business, Management or Economics & Location \\
\hline 36 & Lund University & School of Economics and Management/Master in Innovation and Global Sustainable Development & Sweden \\
\hline 37 & Columbia University & The Earth Institute/M.S. in Sustainability Management & United States \\
\hline 38 & Ecole Polytechnique Federale de Lausanne & College of Management of Technology/MSc in Management, Technology and Entrepreneurship & Switzerland \\
\hline 39 & Technical University of Denmark & Nordic MSc programme in Innovative Sustainable Energy Engineering & Denmark \\
\hline 40 & University of East Anglia & Faculty of Social Science/MA Globalisation, Business and Sustainable Development & United Kingdom \\
\hline 41 & Georgia Institute of Technology & School of Public Policy/Master of Sustainable Energy and Environmental Management & United States \\
\hline 42 & Texas A\&M University & Mays Business School/Center for International Business Studies/The Aggie Sustainability Alliance Certification & United States \\
\hline 43 & University of Leeds & Faculty of Environment/MSc in Sustainability and Business & United Kingdom \\
\hline 44 & Pennsylvania State University & $\begin{array}{c}\text { PennState Smeal College of Business/Graduate Certificate in Business Sustainability Strategy/Center for the } \\
\text { business of sustainability }\end{array}$ & United States \\
\hline 45 & University of Illinois at Urbana-Champaign & Department of Urban \& Regional Planning/MSc in Sustainable Urban Management & United States \\
\hline 46 & Utrecht University & Copernicus Institute of Sustainable/MSc in Sustainable Business and Innovation & Netherlands \\
\hline 47 & The University of Exeter & University of Exeter Business School/MSc Management with module in Sustainability, CSR and Business Ethics & United Kingdom \\
\hline 48 & University College London & UCL Institute for Sustainable Resources/MSc in Environment and Sustainable Development & United Kingdom \\
\hline 49 & The University of Hong Kong & Faculty of Science/MSc in Environmental Management & Hong Kong SAR \\
\hline 50 & Arizona State University & W. P. Carey School of Business/MBA with specializations in Sustainable Enterprise & United States \\
\hline
\end{tabular}

Source: QS Top University. 


\section{Results and Discussion}

\subsection{AAI Rankings}

The authors used the top 50 journals in the categories of sustainability and environmental studies in social science journals and applied the calculations of the AAI formula as indicated previously. Dataset $x$ includes the top 50 environmental science and sustainability journals ranked in SSCI by the WOS according to their impact factors. Dataset $(x+y)$ contains all authors globally, academics or non-academics. Selected articles included research articles (theoretical and empirical) and research notes, but do not include book reviews, discussions or short comments, etc. The number of articles drawn from each journal $m$ is set to 60 since previous literature [21-24] suggests that the AAI becomes stabilized when the size of $\mathrm{m}$ is bigger than 50 . Therefore, sample articles were obtained for each journal from the latest issue of 2018 until 60 articles were selected. The majority of journals (37 out of 50) in the sample reach had 60 papers as the denominator with a coverage of only one year (2018). For the rest of the 13 journals, we examined from two to seven years' worth of articles to reach a denominator of 60 as shown in Table 3.

Table 3. Sample of some journals and number of year's calculation.

\begin{tabular}{ccc}
\hline Journal & Years & No. of Years \\
\hline Annual Review of Resource Economics & $2016-2018$ & 2 \\
Environment and Urbanization & $2017-2018$ & 2 \\
Environmental Innovation and Societal Transitions & $2017-2018$ & 2 \\
Marine Resource Economics & $2016-2018$ & 2 \\
WIREs Climate Change & $2017-2018$ & 2 \\
Annual Review of Environment and Resources & $2016-2018$ & 3 \\
Environment & $2016-2018$ & 3 \\
Global Environmental Politics & $2016-2018$ & 3 \\
Organization and Environment & $2016-2018$ & 3 \\
Anthropocene Review & $2016-2018$ & 3 \\
Review of Environmental Economics and Policy & $2015-2018$ & 4 \\
Journal of Environment and Development & $2015-2018$ & 4 \\
Progress in Planning & $2012-2018$ & 7 \\
\hline
\end{tabular}

Source: Authors.

As shown in Table 4, the AAI scores ranged from 0.019 to 0.276 . Since Annual Review of Environment and Resources has the highest AAI at 0.276 , this means that $27.6 \%$ of this journal's articles are authored by scholars from the top 50 ranking universities in our dataset. The mean of AAI for the 50 top ranking journals can be obtained as 0.126 . This average of AAI according to our sample can be interpreted to mean that on average $12.6 \%$ of journal articles in the chosen field are authored by scholars from the top 50 top ranking universities as predefined in our dataset. The results of AAI scores in sustainability related studies are interesting compared with other AAI ranking studies. First, the AAI scores in the field of sustainability and environmental science in our peer group are significantly low (range from 0.019 to 0.276$)$. Only eight journals out of 50 (16\%) reached an AAI score greater than 0.200.

For example, a previous study in finance reveals that, on average, the AAIs are relatively higher with the top score being as high as 0.800 [21]. The range in the study of Gorman and Kanet's [23] regarding 23 operations management journals was 0.147 to 0.836 and $52 \%$ of journals in their sample had an AAI of 0.50 or higher. Compared with the results obtained by Guthrie et al. [24], the accounting field also yielded the highest AAI score at 0.795 and displayed higher AAIs on average. Research in transportation [33] followed a similar pattern and displayed the range of AAI scores from 0.090-0.670. 
Table 4. AAI rankings of sustainability and environmental journals.

\begin{tabular}{|c|c|c|}
\hline Journals & AAI & Ranking \\
\hline Annual Review of Environment and Resources & 0.276 & 1 \\
\hline Review of Environmental Economics and Policy & 0.252 & 2 \\
\hline Annual Review of Resource Economics & 0.244 & 3 \\
\hline Climate Policy & 0.236 & 4 \\
\hline Ecology and Society & 0.216 & 5 \\
\hline Marine Resource Economics & 0.214 & 6 \\
\hline Energy Research and Social Science & 0.205 & 7 \\
\hline Journal of Environment and Development & 0.201 & 8 \\
\hline Computers Environment and Urban Systems & 0.186 & 9 \\
\hline Environment and Planning A: Economy and Space & 0.178 & 10 \\
\hline WIREs Climate Change & 0.178 & 11 \\
\hline Environmental Communication: A journal of Nature and Culture & 0.171 & 12 \\
\hline Urban Studies & 0.169 & 13 \\
\hline Sustainable Development & 0.162 & 14 \\
\hline Organization and Environment & 0.160 & 15 \\
\hline Land Use Policy & 0.136 & 16 \\
\hline Habitat International & 0.133 & 17 \\
\hline Journal of Environmental Psychology & 0.126 & 18 \\
\hline Environment and Behavior & 0.125 & 19 \\
\hline Global Environmental Politics & 0.124 & 20 \\
\hline Environmental Innovation and Societal Transitions & 0.124 & 21 \\
\hline International Journal of Sustainable Transportation & 0.124 & 21 \\
\hline Environment and Planning D: Society and Space & 0.121 & 23 \\
\hline Climate and Development & 0.114 & 24 \\
\hline Global Environmental Change & 0.114 & 25 \\
\hline Landscape and Urban Planning & 0.110 & 26 \\
\hline Journal of Environmental Economics and Management & 0.108 & 27 \\
\hline Sustainability & 0.104 & 28 \\
\hline Journal of Sustainable Tourism & 0.104 & 29 \\
\hline Environmental Politics & 0.103 & 30 \\
\hline Progress in Planning & 0.102 & 31 \\
\hline Anthropocene Review & 0.101 & 32 \\
\hline Nature Climate Change & 0.100 & 33 \\
\hline Transportation Research Part D: Transport and Environment & 0.099 & 34 \\
\hline Regional Environmental Change & 0.092 & 35 \\
\hline Urban Forestry and Urban Greening & 0.091 & 36 \\
\hline Environment and Planning B: Urban Analytics and City Science & 0.087 & 37 \\
\hline Energy Policy & 0.084 & 38 \\
\hline Resources Policy & 0.081 & 39 \\
\hline Environment & 0.076 & 40 \\
\hline Ecosystems Services & 0.075 & 41 \\
\hline Regional Studies & 0.066 & 42 \\
\hline Business Strategy and the Environment & 0.063 & 43 \\
\hline Ecological Economics & 0.061 & 44 \\
\hline Marine Policy & 0.059 & 45 \\
\hline Environment and Urbanization & 0.056 & 46 \\
\hline Tourism Management & 0.054 & 47 \\
\hline Corporate Social Responsibility and Environmental Management & 0.049 & 48 \\
\hline Forest Policy and Economics & 0.049 & 49 \\
\hline Environmental Impact Assessment Review & 0.019 & 50 \\
\hline
\end{tabular}

Source: Authors.

To further study the reasons behind such a difference in AAI scores, it is observed that there are frequently many co-authors in the same publications in journals focused on the sustainability and environmental science subject. Actually, we found some academic papers signed by 94 authors (Ecosystem Services) or 88 authors (Nature Climate Change) in total, which significantly reduces the final 
AAI results. Table A2 (in Appendix A) displays the articles with author number count in the data set. We consider that these differences in terms of number of authors among distinctive disciplines occur because, in environmental studies, which is the case in many journals composed in our peer group, the work is carried out through research group projects where many researchers may work together in data collection and experiments, etc. However, in journals closely linked with scope of business or management, papers are usually collaborated among much smaller numbers of researchers.

As we can observe from the AAI ranking, most of the top ranking journals, such as the Review of Environmental Economics and Policy (2nd), Annual Review of Resources Economics (3rd) and Climate Policy (4th), are also within the economics or public administration categories. This result confirms the finding that journals closely linked to management, business or economics may have higher AAI scores due to the relatively fewer number of co-authors. In the case of the journal Annual Review of Environment and Resources (1st), it only has two articles with numerous authors (31 and 19) which increases the AAI scores.

The journal Nature Climate Change, which ranked first according to impact factor of the WOS, only occupied the 33rd position in the AAI's ranking criteria. Similarly, Global Environmental Change dropped from 2nd ranking position of WOS to 25th in AAIs rating. One possible explanation is that these two journals present a very high number of co-authors ( 88 and 39 respectively) in some articles, as shown in Table A2, which dramatically reduces the AAI scoring. AAI is very sensitive to the total number of authors and fewer number of co-authors may result in a higher number of AAI results. In addition, given our peer group of the selected top universities, these two journals are more targeted for publications in this sample.

It is also worth mentioning that some other journals, such as Environment and Planning $A$ (50th position in the WOS), Marine Resource Economics (44th position in the WOS) and Annual Review of Resource Economics (41st position in the WOS), have dramatically higher rankings (10th, 9th and 3rd positions respectively) according to the AAI's method. Others also have higher rankings in AAIs since academics choose these journals to publish their research in environmental and social studies. For example, Sustainability went from 46th position in the WOS to 28th in AAI ranking; International Journal of Sustainable Transportation went from 47th position in the WOS to 21st in AAI ranking; and Climate and Development went from 48th position in the WOS to 24th in AAI ranking.

Table 5 shows journals in our sample that belong to categories such as "Management" and other related categories with the highest number of authors in an article. Thus, the difference in the number of authors is observed (Table A2) between those journals closely linked with a business or management aspect and others only focused on environmental studies. The highest number of authors is 20 for business or management scope journals compared with 94 in Table A2 which marked a remarkable difference, although all journals in this study belong to the categories "Environmental Studies" and "Green and Sustainability Science and Technology" within the Social Sciences Citation Index (SSCI) of WOS. We would like to point out that the difference in terms of number of authors is notable comparing articles in Tables 5 and A2. We believe such a difference is relevant to the categories of journals: Environmental Study, Green and Sustainability Science and Technology or Management, Economics and Business related displines.

Table 5. Number of authors in an article in business, management, economics and public administration journals.

\begin{tabular}{ccc}
\hline Journal & WOS Category & No. Authors \\
\hline Climate Policy & Public Administration; Environmental Studies & 20 \\
Forest Policy and Economics & Economics; Environmental Studies & 20 \\
Regional Studies & Economics; Geography; Regional \& Urban & 14 \\
Review of Environmental Economics and Policy & Planning; Environmental Studies & 13 \\
Ecological Economics & Economics; Environmental Studies & 11 \\
Journal of Sustainable Tourism & Economics; Environmental Studies & \\
\hline
\end{tabular}


Table 5. Cont.

\begin{tabular}{ccc}
\hline Journal & WOS Category & No. Authors \\
\hline $\begin{array}{c}\text { Corporate Social Responsibility and } \\
\text { Environmental Management } \\
\text { Marine Resource Economics }\end{array}$ & Management; Business; Environmental Studies & 10 \\
Journal of Environmental Economics & Economics; Environmental Studies & 10 \\
and Management & Business; Economics; Environmental Studies & 9 \\
Organization and Environment & Management; Environmental Studies & 9 \\
Business Strategy and the Environment & Management; Business; Environmental Studies & 7 \\
Energy Policy & Economics; Environmental Studies & 7 \\
Tourism Management & Management; Hospitality, Leisure, Sport \& & 7 \\
Annual Review of Resource Economics & Tourism; Environmental Studies & 5 \\
\hline
\end{tabular}

Source: Authors.

\subsection{Comparison of AAI Ranking with Other Ranking Measures}

We aimed to describe and examine the usefulness of AAI method in green, sustainability and environmental science journals to see if the top 50 ranked universities in these disciplines actually publish in the top 50 ranked journals of the same field. A comparison of AAI ranking with other ranking measures was carried out accordingly. We considered that such comparison of AAI score with other established measures (both of citation and survey based) was important, although the existing ranking measures do not set any peer group as the AAI method does.

Several criteria of ranking metrics were adopted as shown in Table 6. The Journal Impact Factor (JIF) from Web of Science "is a measure of the frequency with which the 'average article' in a journal has been cited in a particular year or period" [51]. As we can see from Table 6, the journal rankings have displayed a very different pattern comparing the AAI and JIF citation-based ranking. Among the top 10 journals ranked by JIF 2018, just two journals (Annual Review of Environment and Resources and Review of Environmental Economics and Policy) actually stay within the top 10 list according to AAI.

Two ranking metrics were drawn from Scopus. These were Scientific Journal Rankings (SJR) and Source Normalized Impact per Paper (SNIP). SJR metric is based on the idea that "all citations are not created equal" [52]. With SJR, the subject field, quality and reputation of the journal have a direct effect on the value of a citation. SNIP is an indicator that measures the average citation impact of the publications of a journal and corrects for differences in citation practices between scientific fields so as to provide more accuracy between field comparisons of citation impact [52]. As observed in Table 6, SJR and SNIP rankings display a relatively more similar pattern towards ranking. In general, the results of JIF, SJR and SNIP rankings have shown agreement on the first ranking journal, Nature Climate Change. To compare these two Scopus rankings with AAI, the results show a very disperse pattern. Only the journal Annual Review of Environment and Resources presents a very similar ranking among all four ranking methods.

The Academic Journal Guide (AJG) released by the Chartered Association of Business Schools [53] was also added for further comparison. The AJG is a guide to the range and quality of journals in which business and management researchers published their research. The AJG metric is based upon peer review and editorial and expert judgments following the evaluation of publications. The ratings are given as four categories from 1-4 in which a ranking of 4 indicates that journals represent those of distinction within the business and management field. In this case, we may see that some journals, such as Nature Climate Change which are not within the aforementioned fields, have not obtained any rating for AJG. There are 19 out of 50 journals rated by AJG in the economics, business and management fields. Upon the available ratings of journals based on the ABS list, the Environment and Planning A: Economy and Space journal ranked as the 10th in AAI scores and obtained an AJG rating 4 as a distinction journal. The Corporate Social Responsibility and Environmental Management journal has a 1 for AJG rating and occupied the 48th position in the AAIs measure. However, the Tourism Management journal, which also has a distinction rating on the ABS list, ranked as 47th in AAI. For our observations, not much agreement can be reached simply comparing between AJG and AAI ranking methods. 
Table 6. Ranking of sustainability journals.

\begin{tabular}{|c|c|c|c|c|c|}
\hline Journals & $\begin{array}{c}\text { AAI } \\
\text { Rank }\end{array}$ & $\begin{array}{l}\text { JIF Rank } \\
\text { (WOS) }\end{array}$ & $\begin{array}{l}\text { SJR Rank } \\
\text { (Scopus) }\end{array}$ & $\begin{array}{l}\text { SNIP Rank } \\
\text { (Scopus) }\end{array}$ & $\begin{array}{l}\text { AJG Class } \\
\text { (ABS) }\end{array}$ \\
\hline Nature Climate Change & 33 & 1 & 1 & 1 & - \\
\hline $\begin{array}{l}\text { Global Environmental Change: Human and } \\
\text { Policy Dimensions }\end{array}$ & 25 & 2 & 2 & 5 & 3 \\
\hline Annual Review of Environment and Resources & 1 & 3 & 3 & 4 & - \\
\hline Organization and Environment & 15 & 4 & 9 & 8 & 2 \\
\hline Environmental Innovation and Societal Transitions & 21 & 5 & 5 & 14 & - \\
\hline WiREs Climate Change & 11 & 6 & 4 & 6 & - \\
\hline Review of Environmental Economics and Policy & 2 & 7 & 7 & 9 & 2 \\
\hline Business Strategy and the Environment & 43 & 8 & 12 & 10 & 3 \\
\hline Tourism Management & 47 & 9 & 6 & 3 & 4 \\
\hline Ecosystem Services & 41 & 10 & 13 & 24 & - \\
\hline Energy Research and Social Science & 7 & 11 & 14 & 27 & - \\
\hline $\begin{array}{l}\text { Corporate Social Responsibility and } \\
\text { Environmental Management }\end{array}$ & 48 & 12 & 27 & 12 & 1 \\
\hline Landscape and Urban Planning & 26 & 13 & 23 & 11 & - \\
\hline Energy Policy & 38 & 14 & 20 & 25 & 2 \\
\hline Climate Policy & 4 & 15 & 18 & 32 & - \\
\hline Ecological Economics & 44 & 16 & 25 & 22 & 3 \\
\hline $\begin{array}{l}\text { Journal of Environmental Economics } \\
\text { and Management }\end{array}$ & 27 & 17 & 11 & 18 & 3 \\
\hline Ecology and Society & 5 & 18 & 24 & 33 & - \\
\hline Environment and Behavior & 19 & 19 & 30 & 16 & - \\
\hline $\begin{array}{c}\text { Transportation Research Part D: Transport } \\
\text { and Environment }\end{array}$ & 34 & 20 & 31 & 19 & 3 \\
\hline Progress in Planning & 31 & 21 & 15 & 2 & - \\
\hline Habitat International & 17 & 22 & 29 & 21 & - \\
\hline Environmental Politics & 30 & 23 & 26 & 36 & - \\
\hline Sustainable Development & 14 & 24 & 46 & 34 & - \\
\hline Environmental Impact Assessment Review & 50 & 25 & 33 & 26 & - \\
\hline Journal of Environmental Psychology & 18 & 26 & 21 & 20 & - \\
\hline Land Use Policy & 16 & 27 & 34 & 30 & - \\
\hline Journal of Sustainable Tourism & 29 & 28 & 35 & 28 & 3 \\
\hline Global Environmental Politics & 20 & 29 & 17 & 37 & - \\
\hline Computers Environment and Urban Systems & 9 & 30 & 38 & 13 & - \\
\hline Urban Studies & 13 & 31 & 16 & 15 & 3 \\
\hline Resources Policy & 39 & 32 & 41 & 29 & 2 \\
\hline Environment & 40 & 33 & 44 & 48 & - \\
\hline Journal of Environment and Development & 8 & 34 & 43 & 38 & - \\
\hline Regional Environmental Change & 35 & 35 & 39 & 44 & - \\
\hline Anthropocene Review & 32 & 36 & 8 & 7 & - \\
\hline Forest Policy and Economics & 49 & 37 & 36 & 42 & - \\
\hline Regional Studies & 42 & 38 & 10 & 17 & 3 \\
\hline Urban Forestry and Urban Greening & 36 & 39 & 47 & 35 & - \\
\hline Environment and Urbanization & 46 & 40 & 32 & 31 & - \\
\hline Annual Review of Resource Economics & 3 & 41 & 22 & 39 & 2 \\
\hline Marine Policy & 45 & 42 & 37 & 40 & 2 \\
\hline $\begin{array}{c}\text { Environment and Planning B: Urban Analytics and } \\
\text { City Science }\end{array}$ & 37 & 43 & 48 & 50 & - \\
\hline Marine Resource Economics & 6 & 44 & 49 & 47 & 1 \\
\hline Environment and Planning D: Society and Space & 23 & 45 & 19 & 23 & 4 \\
\hline Sustainability & 28 & 46 & 50 & 46 & - \\
\hline International Journal of Sustainable Transportation & 21 & 47 & 40 & 45 & - \\
\hline Climate and Development & 24 & 48 & 45 & 49 & - \\
\hline $\begin{array}{l}\text { Environmental Communication: A Journal of Nature } \\
\text { and Culture }\end{array}$ & 12 & 49 & 42 & 40 & - \\
\hline Environment and Planning A: Economy and Space & 10 & 50 & 28 & 43 & 4 \\
\hline
\end{tabular}

Source: Authors.

\section{Conclusions}

Many authors have studied and proposed methods and numerous indexes that provide alternative quality measures of different academic journals in diverse fields of study. In this research, the AAI method was applied in the sustainability field in social science journals as a preliminary study to offer some insights into the quality rating of journals. According to Chan et al. [19], the reasoning of AAI is that a prestigious journal tends to attract scholars from top-notch universities or institutions to publish their research work. Therefore, high AAI scores for a journal represents high journal quality because leading scholars produce quality research articles in general. 
The results obtained demonstrate that there is a lower AAI score on average in the sustainability field compared with other disciplines such as finance, accounting, transportation, etc. The low scoring is probably caused by the high number of co-authors collaborating in environmental studies journals composed in the peer group. However, we have to bear in mind that, in addition to the sustainability studies category, many journals are also within the business or management disciplines which have shown a much lower number of authors on average in our sample. The average of AAI according to our sample can be interpreted as that, on average, $12.6 \%$ of journal articles in the chosen field are authored by academics or scholars from the top 50 ranking universities in our dataset. This result confirms an elite affiliation effect, in which leading sustainability journals have higher concentration of authors who are affiliated with elite institutions. However, such elite affiliation effects are very low, which can be caused by other factors (number of authors, etc.).

Comparing AAI ranking with other ranking measures, such as the JIF from Web of Sciences, SJR and SNIP from Scopus and AJG from Chartered Association of Business Schools, there are no consistent rating results obtained. The three citation-based ranking method (JIF, SJR and SNIP) has displayed relatively similar ranking results, especially for the top 10 rated journals. Only two journals, Annual Review of Environment and Resources and Review of Environmental Economics and Policy, align with the top 10 ranking journals in AAIs and the citation-based measures. To conclude, our AAI-based journal ranking is not correlated with the rankings in other measures.

Since AAI is based on the principle that as the percentage of authors in a journal who are from the top-ranking universities increases, the perceived value of that journal in terms of quality to these universities also increases. We confirm the publication by top-ranking universities with these postgraduate study subjects in the top-rated journals. Nevertheless, due to the large number of co-authors in the selected journals, we cannot observe a very high value of AAIs in this field.

However, we know that this method has certain limitations. Gorman and Kanet [23] have indicated that "... Any objective measure of journal quality, which is inherently subjective, will have its defects, but measures such as the AAI do provide value ..." (p. 17). In this sense, we agree with Agrawal et al. [54] and Fry and Donohue [55] that the use of author affiliations to assess whether a journal is prestigious or not is still relatively new and it is necessary to continue analyzing it.

Another limitation is the complication encountered at the time of collecting information to separate academics by departments or areas of study in order to determine the journals they are attracted to present and publish their research work in. But we believe that our sample is representative in terms of selection of academics and journals related to sustainability issues.

Nevertheless, the use of author affiliations to assess the reputation of institutions and journals has been widely accepted and applied in many academic disciplines and by many authors. Therefore, we consider that the AAI is a method that provides an alternative ranking for journals besides other citation and survey-based ranking measures.

Similarly, we consider that productivity of scholars is not only measured by the journals in which the results of their research are published. Other aspects must be taken into account, but these aspects are beyond the purpose of this paper. Future research can be done to combine the AAI measure with other aspects for assessing quality of scholars' research work and journals. Other ranking criteria besides the QS Top University ranking can also be considered.

Author Contributions: M.G. and X.L. contributed equally to the development of the research and reports. All authors have read and agreed to the published version of the manuscript.

Funding: This research received no external funding.

Conflicts of Interest: The authors declare no conflict of interest. 


\section{Appendix A}

Table A1. Web of Science (WOS) rankings of sustainability and environmental journals.

\begin{tabular}{|c|c|c|c|}
\hline Rank 2018 & Journal & Category & Journal Impact Factor (WOS) \\
\hline 1 & Nature Climate Change & Environmental Studies & 21.722 \\
\hline 2 & Global Environmental Change: Human and Policy Dimensions & Geography; Environmental Studies & 10.427 \\
\hline 3 & Annual Review of Environment and Resources & Environmental Studies & 8.617 \\
\hline 4 & Organization and Environment & Management; Environmental Studies & 8.500 \\
\hline 6 & WIREs Climate Change & Environmental Studies & 7.057 \\
\hline 7 & Review of Environmental Economics and Policy & Economics; Environmental Studies & 6.649 \\
\hline 8 & Business Strategy and the Environment & Management; Business; Environmental Studies & 6.381 \\
\hline 9 & Tourism Management & $\begin{array}{l}\text { Management; Hospitality, Leisure, Sport \& Tourism; } \\
\text { Environmental Studies }\end{array}$ & 6.012 \\
\hline 10 & Ecosystem Services & Environmental Studies & 5.572 \\
\hline 11 & Energy Research and Social Science & Environmental Studies & 5.525 \\
\hline 12 & Corporate Social Responsibility and Environmental Management & Management; Business; Environmental Studies & 5.513 \\
\hline 13 & Landscape and Urban Planning & $\begin{array}{c}\text { Geography; Regional \& Urban Planning; Urban Studies; } \\
\text { Environmental Studies }\end{array}$ & 5.144 \\
\hline 14 & Energy Policy & Economics; Environmental Studies & 4.880 \\
\hline 15 & Climate Policy & Environmental Studies; Public Administration & 4.797 \\
\hline 16 & Ecological Economics & Economics; Environmental Studies & 4.281 \\
\hline 17 & Journal of Environmental Economics and Management & Business; Economics; Environmental Studies & 4.175 \\
\hline 18 & Ecology and Society & Environmental Studies & 4.136 \\
\hline 19 & Environment and Behavior & Psychology, Multidisciplinary; Environmental Studies & 4.093 \\
\hline 21 & Progress in Planning & Regional \& Urban Planning; Environmental Studies & 3.875 \\
\hline 22 & Habitat International & $\begin{array}{c}\text { Development Studies; Regional \& Urban Planning; Urban Studies; } \\
\text { Environmental Studies }\end{array}$ & 3.846 \\
\hline 23 & Environmental Politics & Political Science; Environmental Studies & 3.827 \\
\hline 24 & Sustainable Development & $\begin{array}{c}\text { Development Studies; Green \& Sustainable Science \& Technology; } \\
\text { Regional \& Urban Planning }\end{array}$ & 3.821 \\
\hline 25 & Environmental Impact Assessment Review & Environmental Studies & 3.749 \\
\hline 26 & Journal of Environmental Psychology & Psychology, Multidisciplinary; Environmental Studies & 3.626 \\
\hline 27 & Land Use Policy & Environmental Studies & 3.573 \\
\hline 28 & Journal of Sustainable Tourism & $\begin{array}{c}\text { Hospitality, Leisure, Sport \& Tourism; Green \& Sustainable } \\
\text { Science \& Technology }\end{array}$ & 3.400 \\
\hline 29 & Global Environmental Politics & International Relations; Political Science; Environmental Studies & 3.397 \\
\hline 30 & Computers Environment and Urban Systems & Geography; Regional \& Urban Planning; Environmental Studies & 3.393 \\
\hline
\end{tabular}


Table A1. Cont.

\begin{tabular}{|c|c|c|c|}
\hline Rank 2018 & Journal & Category & Journal Impact Factor (WOS) \\
\hline 31 & Urban Studies & Urban Studies; Environmental Studies & 3.272 \\
\hline 32 & Resources Policy & Environmental Studies & 3.185 \\
\hline 33 & Environment & Environmental Studies & 3.176 \\
\hline 34 & Journal of Environment and Development & $\begin{array}{l}\text { Development Studies; Regional \& Urban Planning; } \\
\text { Environmental Studies }\end{array}$ & 3.156 \\
\hline 35 & Regional Environmental Change & Environmental Studies & 3.149 \\
\hline 36 & Anthropocene Review & Environmental Studies & 3.111 \\
\hline 37 & Forest Policy and Economics & Economics; Environmental Studies & 3.099 \\
\hline 38 & Regional Studies & $\begin{array}{c}\text { Economics; Geography; Regional \& Urban Planning; } \\
\text { Environmental Studies }\end{array}$ & 3.074 \\
\hline 39 & Urban Forestry and Urban Greening & Urban Studies; Environmental Studies & 3.043 \\
\hline 40 & Environment and Urbanization & Urban Studies; Environmental Studies & 3.015 \\
\hline 41 & Annual Review of Resource Economics & Economics; Environmental Studies & 2.978 \\
\hline 42 & Marine Policy & International Relations; Environmental Studies & 2.865 \\
\hline 43 & Environment and Planning B: Urban Analytics and City Science & $\begin{array}{c}\text { Geography; Regional \& Urban Planning; Urban Studies; } \\
\text { Environmental Studies }\end{array}$ & 2.825 \\
\hline 44 & Marine Resource Economics & Economics; Environmental Studies & 2.800 \\
\hline 45 & Environment and Planning D: Society and Space & Geography; Environmental Studies & 2.730 \\
\hline 46 & Sustainability & Green \& Sustainable Science \& Technology; Environmental Studies & 2.592 \\
\hline 47 & International Journal of Sustainable Transportation & $\begin{array}{c}\text { Green \& Sustainable Science \& Technology; Transportation; } \\
\text { Environmental Studies }\end{array}$ & 2.586 \\
\hline 49 & Environmental Communication: A Journal of Nature and Culture & Communication; Environmental Studies & 2.469 \\
\hline 50 & Environment and Planning A. Economy and Space & Geography; Environmental Studies & 2.459 \\
\hline
\end{tabular}


Table A2. Top 10 articles by author count.

\begin{tabular}{|c|c|c|c|c|c|}
\hline Title & Authors & No. Authors & Year & Journal & DOIs \\
\hline $\begin{array}{l}\text { Stakeholders' perspectives on the } \\
\text { operationalisation of the ecosystem service } \\
\text { concept: Results from } 27 \text { case studies }\end{array}$ & $\begin{array}{l}\text { Dick, J., Turkelboom, F., Woods, H., (...), } \\
\text { Yli-Pelkonen, V., Zulian, G. }\end{array}$ & 94 & 2018 & Ecosystem Services & DOI: 10.1016/j.ecoser.2017.09.015 \\
\hline $\begin{array}{l}\text { Global phenological insensitivity to shifting } \\
\text { ocean temperatures among seabirds }\end{array}$ & $\begin{array}{l}\text { Keogan, K., Daunt, F., Wanless, S., (...), } \\
\text { Phillimore, A.B., Lewis, S. }\end{array}$ & 88 & 2018 & Nature Climate Change & DOI: 10.1038/s41558-018-0115-z \\
\hline $\begin{array}{l}\text { Latitudinal limits to the predicted increase of the } \\
\text { peatland carbon sink with warming }\end{array}$ & $\begin{array}{l}\text { Gallego-Sala, A.V., Charman, D.J., } \\
\text { Brewer, S., (...), Zaragoza-Castells, J., } \\
\text { Zhao, Y. }\end{array}$ & 75 & 2018 & Nature Climate Change & DOI: 10.1038/s41558-018-0271-1 \\
\hline $\begin{array}{l}\text { Spatial scales of marine conservation } \\
\text { management for breeding seabirds }\end{array}$ & $\begin{array}{l}\text { Oppel, S., Bolton, M., Carneiro, A.P.B., } \\
\text { (...), González-Solís, J., Croxall, J. }\end{array}$ & 72 & 2018 & Marine Policy & DOI: 10.1016/j.marpol.2018.08.024 \\
\hline $\begin{array}{l}\text { Similar estimates of temperature impacts on } \\
\text { global wheat yield by three } \\
\text { independent methods }\end{array}$ & $\begin{array}{l}\text { Liu, B., Asseng, S., Müller, C., (...), } \\
\text { Zhao, Z., Zhu, Y. }\end{array}$ & 62 & 2016 & Nature Climate Change & DOI: $10.1038 /$ nclimate3115 \\
\hline $\begin{array}{l}\text { Integrating methods for ecosystem service } \\
\text { assessment: Experiences from real world } \\
\text { situations }\end{array}$ & $\begin{array}{l}\text { Dunford, R., Harrison, P., Smith, A., (...), } \\
\text { Woods, H., Yli-Pelkonen, V. }\end{array}$ & 48 & 2018 & Ecosystem Services & DOI: 10.1016/j.ecoser.2017.10.014 \\
\hline $\begin{array}{l}\text { Ten essentials for action-oriented and second } \\
\text { order energy transitions, transformations and } \\
\text { climate change research }\end{array}$ & $\begin{array}{l}\text { Fazey, I., Schäpke, N., Caniglia, G., (...), } \\
\text { Woods, M., Wyborn, C. }\end{array}$ & 48 & 2018 & $\begin{array}{l}\text { Energy Research and } \\
\text { Social Science }\end{array}$ & DOI: 10.1016/j.erss.2017.11.026 \\
\hline $\begin{array}{l}\text { The Shared Socioeconomic Pathways and their } \\
\text { energy, land use, and greenhouse gas emissions } \\
\text { implications: An overview }\end{array}$ & $\begin{array}{l}\text { Riahi, K., van Vuuren, D.P., Kriegler, E., } \\
\text { (...), Tabeau, A., Tavoni, M. }\end{array}$ & 46 & 2017 & Global Environmental Change & DOI: 10.1016/j.gloenvcha.2016.05.009 \\
\hline $\begin{array}{l}\text { Biophysical and economic limits to negative } \\
\qquad \mathrm{CO}_{2} \text { emissions }\end{array}$ & $\begin{array}{l}\text { Smith, P., Davis, S.J., Creutzig, F., (...), } \\
\text { Edmonds, J., Yongsung, C. }\end{array}$ & 40 & 2016 & Nature Climate Change & DOI: $10.1038 /$ nclimate2870 \\
\hline $\begin{array}{l}\text { Unsustainable landscapes of deforested } \\
\text { Amazonia: An analysis of the relationships } \\
\text { among landscapes and the social, economic and } \\
\text { environmental profiles of farms at different ages } \\
\text { following deforestation }\end{array}$ & $\begin{array}{l}\text { Lavelle, P., Dolédec, S., de Sartre, X.A., } \\
\text { (...), Velasquez, E., Velasquez, J. }\end{array}$ & 39 & 2016 & Global Environmental Change & DOI: 10.1016/j.gloenvcha.2016.04.009 \\
\hline $\begin{array}{l}\text { How private are Europe's private forests? A } \\
\text { comparative property rights analysis }\end{array}$ & $\begin{array}{l}\text { Nichiforel, L., Keary, K., Deuffic, P., (...), } \\
\text { Wilkes-Allemann, J., Bouriaud, L. }\end{array}$ & 39 & 2018 & Land Use Policy & DOI: 10.1016/j.landusepol.2018.02.034 \\
\hline $\begin{array}{l}\text { (Dis) integrated valuation-Assessing the } \\
\text { information gaps in ecosystem service } \\
\text { appraisals for governance support }\end{array}$ & $\begin{array}{l}\text { Barton, D.N., Kelemen, E., Dick, J., (...), } \\
\text { Mukhopadhyay, R., Lapola, D.M. }\end{array}$ & 37 & 2018 & Ecosystem Services & DOI: 10.1016/j.ecoser.2017.10.021 \\
\hline $\begin{array}{l}\text { When we cannot have it all: Ecosystem services } \\
\text { trade-offs in the context of spatial planning }\end{array}$ & $\begin{array}{l}\text { Turkelboom, F., Leone, M., Jacobs, S., (...), } \\
\text { Luque, S., Rusch, V. }\end{array}$ & 37 & 2018 & Ecosystem Services & DOI: 10.1016/j.ecoser.2017.10.011 \\
\hline
\end{tabular}

Source: Authors. 


\section{References}

1. Jangid, N.; Saha, S.; Gupta, S.; Rao, J.M. Ranking of Journals in Science and Technology Domain: A Novel and Computationally Lightweight Approach. IERI Procedia 2014, 10, 57-62. [CrossRef]

2. Kao, E.; Hsu, C.; Lu, Y.; Fung, H. Ranking of finance journals: A stochastic dominance analysis. Manag. Financ. 2016, 42, 312-323. [CrossRef]

3. Álvarez-García, J.; del RíoRama, M.C. Sustainability and EMAS: Impact of motivations and barriers on the perceived benefits from the adoption of standards. Sustainability 2016, 8, 1057. [CrossRef]

4. Korman, A.M.; Joselow, A.; Mounessa, J.S.; Buntinx-Krieg, T.; Varedi, A.; Dellavalle, R.P. A Comparison of Academic Journal Impact in Dermatology vs. Similarly Sized Medical Specialties. Curr. Dermatol. Rep. 2017, 6, 309-315. [CrossRef]

5. Vogel, R.; Hattke, F.; Petersen, J. Journal rankings in management and business studies: What rules do we play by? Res. Pol. 2017, 46, 1707-1722. [CrossRef]

6. Olawuyi, S.O.; Mushunje, A. Social capital and adoption of alternative conservation agricultural practices in South-Western Nigeria. Sustainability 2019, 11, 716. [CrossRef]

7. Rafols, I.; Leydesdorff, L.; O'Hare, A.; Nightingale, P.; Stirling, A. How journal rankings can suppress interdisciplinary research. A comparison between Innovation Studies and Business \& Management. Res. Pol. 2012, 41, 1262-1282.

8. Mendonça Neto, O.R.; Lopes Cardoso, R.; Tiomatsu Oyadomari, J.C. Os periódicos de maior impacto na pesquisa contábil Brasileira e Norte-Americana: Uma análise comparativa baseada nas citações em teses de doutorado. Perspect. Ciência Inf. 2011, 16, 93-115.

9. Liu, N.C.; Cheng, Y. The Academic Ranking of World Universities. High. Educ. Eur. 2005, 30, 127-136. [CrossRef]

10. Bullock, R.; Kirchhoff, D.; Mauro, I.; Boerchers, M. Indigenous capacity for collaboration in Canada's energy, forestry and mining sectors: Research metrics and trends. Environ. Dev. Sustain. 2018, 20, 883-895. [CrossRef]

11. Herrero-Jáuregui, C.; Arnaiz-Schmitz, C.; Reyes, M.F.; Telesnicki, M.; Agramonte, I.; Easdale, M.H.; Schmitz, M.F.; Aguiar, M.; Gómez-Sal, A.; Montes, C. What do we talk about when we talk about social-ecological systems? A literature review. Sustainability 2018, 10, 2950. [CrossRef]

12. Wang, C.-Y.; Li, B.-H.; Ma, L.-L.; Zhao, M.-J.; Deng, T.; Jin, Y.-H.; Ren, X.-Q. The top-100 highly cited original articles on drug therapy for ventilator-associated pneumonia. Front. Pharmacol. 2019, 10, 108. [CrossRef] [PubMed]

13. Zhong, Q.; Li, B.-H.; Zhu, Q.-Q.; Zhang, Z.-M.; Zou, Z.-H.; Jin, Y.-H. The top 100 highly cited original articles on immunotherapy for childhood leukemia. Front. Pharmacol. 2019, 10, 1100. [CrossRef]

14. Ul Haq, I.; Elahi, G.; Dana, I. Research Publications on Medical Microbiology in Pakistan during the period 2013-2017. Libr. Philos. Pract. 2019, 2019, 2253.

15. Xie, J.; Sun, L. A content analysis of Journal of Library Science in China in 2007-2016. J. Electron. Resour. Librariansh. 2018, 30, 185-197. [CrossRef]

16. Srivastava, M.; Rogers, H.; Lettice, F. Team performance management: Past, current and future trends. Team Perform. Manag. 2013, 19, 352-362. [CrossRef]

17. Jesiek, B.K.; Borrego, M.; Beddoes, K.; Hurtado, M.; Rajendran, P.; Sangam, D. Mapping global trends in engineering education research, 2005-2008. Int. J. Eng. Educ. 2011, 27, 77-90.

18. Cui, S.; Li, W.; Yi, L.; Li, C.; Zhu, L.; Jiang, Z. A bibliometrical analysis of status on animal behavior in China. Acta Theriol. Sin. 2016, 36, 476-484.

19. Chan, K.C.; Tong, J.Y.; Zhang, F.F. Accounting Journal Rankings, Authorship Patterns and the Author Affiliation Index. Aust. Account. Rev. 2012, 22, 407-417. [CrossRef]

20. Chan, K.C.; Chen, C.R.; Cheng, L.T.W. Global ranking of accounting programmes and the elite effect in accounting research. Account. Financ. 2007, 47, 187-220. [CrossRef]

21. Chen, C.R.; Huang, Y. Author Affiliation Index, finance journal ranking, and the pattern of authorship. J. Corp. Financ. 2007, 13, 1008-1026. [CrossRef]

22. Cronin, B.; Meho, L.I. Applying the author affiliation index to library and information science journals. J. Am. Soc. Inf. Sci. Technol. 2008, 59, 1861-1865. [CrossRef]

23. Gorman, M.F.; Kanet, J.J. Evaluating Operations Management-Related Journals via the Author Affiliation Index. Manuf. Serv. Oper. Manag. 2005, 7, 3-19. [CrossRef] 
24. Guthrie, C.P.; Everett, J.O.; Vijayakumar, J.; Olds, P.R. Evaluating faculty publications in accounting Ph.D. programs: The Author Affiliation Index as an alternative. J. Account. Educ. 2012, 30, 290-306. [CrossRef]

25. Wilhite, A.W.; Fong, E.A. Coercive citation in academic publishing. Science 2012, 335, 542-543. [CrossRef]

26. Howard, G.S. Research productivity in counseling psychology: An update and generalization study. J. Couns. Psychol. 1983, 30, 600-602. [CrossRef]

27. Hull, R.P.; Wright, G.B. Faculty perceptions of journal quality: An update. Account. Horiz. 1990, 4, 77-98.

28. Jolly, S.A.; Schroeder, R.G.; Spear, R.K. An empirical investigation of the relationship between journal quality ratings and promotion and tenure decisions. Account. Educ. J. 1995, 7, 47-68.

29. Bonner, S.E.; Hesford, J.W.; Van der Stede, W.A.; Young, S.M. The most influential journals in academic accounting. Account. Organ. Soc. 2006, 31, 663-685. [CrossRef]

30. Chan, K.C.; Liano, K. Threshold Citation Analysis of Influential Articles, Journals, Institutions and Researchers in Accounting. Account. Financ. 2009, 49, 59-74. [CrossRef]

31. Moosa, I. The Demise of the ARC Journal Ranking Scheme: An Ex Post Analysis of the Accounting and Finance Journal. Account. Financ. 2011, 51, 809-836. [CrossRef]

32. Harless, D.; Reilly, R. Revision of the Journal List for Doctoral Designation; Unpublished report; Virginia Commonwealth University: Richmond, VA, USA, 1998; Available online: https://www.researchgate. net/publication/228108187_Revision_of_the_journal_list_for_doctoral_designation_Unpublished_report (accessed on 25 June 2019).

33. Gorman, M.F.; Kanet, J.J.; Christ, D. Evaluating Transportation Research Journal Quality Using the Author Affiliation Index. Transp. J. 2011, 50, 370-389. [CrossRef]

34. Ferratt, T.W.; Gorman, M.F.; Kanet, J.J.; Salisbury, W.D. IS Journal Quality Assessment Using the Author Affiliation Index. Commun. Assoc. Inf. Syst. 2007, 19, 710-724. [CrossRef]

35. Heck, J.L. Establishing a pecking order for finance academics: Ranking of U.S. finance doctoral programs. Rev. Pac. Basin Finan. Mark. Pol. 2007, 10, 479-490. [CrossRef]

36. Lasser, D.; Rydqvist, K. Ranking Journals by Concentration of Author Affiliation: Thirty-Five Years of Finance Research; Discussion Paper No. 5731; Centre for Economic Policy Research: London, UK, 2006.

37. Sousa, P.S.A.; Vieira, P.C.C. Universities and authors: A ranking for international finance. Econ. Bull. 2011, 31, 507-518.

38. Mathieu, R.; McConomy, B.J. Productivity in "top-ten" academic accounting journals by researchers at Canadian universities. Can. Account. Perspect. 2003, 2, 43-76. [CrossRef]

39. Conroy, M.E.; Dusansky, R.; Drukker, D.; Kildegaard, A. The productivity of economics departments in the U.S.: Publications in the core journals. J. Econ. Lit. 1995, 33, 1966-1971.

40. Coupe, T. Revealed performances: Worldwide rankings of economists and economics departments, 1990-2000. J. Eur. Econ. Assoc. 2003, 1, 1309-1345. [CrossRef]

41. Hogan, T.D. Economics departmental rankings: Comment. Am. Econ. Rev. 1984, 74, 827-833.

42. Jin, J.C.; Hong, J.H. East Asian rankings of economics departments. J. Asian. Econ. 2008, 19, 74-82. [CrossRef]

43. TopUniversities. Available online: https://www.topuniversities.com/university-rankings/university-subjectrankings/2018/environmental-studies (accessed on 27 July 2019).

44. Hernandez-de-Menendez, M.; Morales-Menendez, R. Technological innovations and practices in engineering education: A review. Int. J. Interact. Des. Manuf. 2019, 13, 713-728. [CrossRef]

45. Pilishvili, T.; Karabushchenko, N.; Magomedova, E.; Roseanne, R.; Medvedeva, I. The top 50 universities for psychology: Educational and future career trends for students. Revista ESPACIOS 2018, 39, 1-13.

46. Tejedor Calvo, S.; Cervi, L. Analysis of the journalism and communication degree programmes of the world's top-ranked universities. Competencies, objectives and subjects. Rev. Lat. Comun. Soc. 2017, 72, 1626-1647.

47. Gopal, K.; Shitan, M. Cluster analysis of top 200 universities in Mathematics. In Proceedings of the 2015 International Symposium on Mathematical Sciences and Computing Research, iSMSC 2015—Proceedings, Ipon, Malaysia, 19-20 May 2015; pp. 408-413.

48. Culquichicón, C.; Helguero-Santin, L.M.; Labán-Seminario, L.M.; Cardona-Ospina, J.A.; Aboshady, O.A.; Correa, R. Massive open online courses in health sciences from Latin American institutions: A need for improvement? F1000 Res. 2017, 6, 940. [CrossRef] [PubMed]

49. Klochkov, Y. Analysis of the Publication Activity of University Researchers. In Proceedings of the 2019 Amity International Conference on Artificial Intelligence (AICAI), Dubai, United Arab Emirates, 4-6 February 2019; Volume 8701280, pp. 74-79. 
50. Rodionov, D.G.; Rudskaia, I.A.; Alexandrovna, K.O. How key Russian Universities advance to become leaders of worldwide education: Problem analysis and solving. World Appl. Sci. J. 2014, 31, 1082-1089.

51. Web of Science Group. Available online: https://clarivate.com/webofsciencegroup/essays/impact-factor/ (accessed on 7 January 2020).

52. Colledge, L.; de Moya-Anegón, F.; Guerrero-Bote, V.P.; López-Illescas, C.; Moed, H.F. SJR and SNIP: Two new journal metrics in Elsevier's Scopus. Insights 2010, 23, 215-231. [CrossRef]

53. Chartered Association of Business Schools (CABS). Available online: https://charteredabs.org/academicjournal-guide-2018/ (accessed on 7 January 2020).

54. Agrawal, V.K.; Agrawal, V.; Rungtusanatham, M. Theoretical and Interpretation Challenges to Using the Author Affiliation Index Method to Rank Journals. Prod. Oper. Manag. Soc. 2011, 20, 280-300. [CrossRef]

55. Fry, T.D.; Donohue, J.M. Exploring the Author Affiliation Index. Scientometrics 2014, 98, 1647-1667. [CrossRef]

(C) 2020 by the authors. Licensee MDPI, Basel, Switzerland. This article is an open access article distributed under the terms and conditions of the Creative Commons Attribution (CC BY) license (http://creativecommons.org/licenses/by/4.0/). 